\title{
UPAYA MENINGKATKAN AKTIVITAS DAN PRESTASI BELAJAR SISWA KELAS XI PADA MATA PELAJARAN PENDIDIKAN PANCASILA DAN KEWARGANEGARAAN (PKWN) MELALUI MODEL PEMBELAJARAN JIGSAW DI SMK NW TEMBENG PUTIK TAHUN PELAJARAN 2021/2022
}

\author{
MASHUN \\ STAI Darul Kamal NW Kembang Kerang Lotim NTB \\ mashunonk@gmail.com \\ SRI WAHYUNI \\ STAI Darul Kamal NW Kembang Kerang Lotim NTB \\ cutesry08@gmail.com
}

\begin{abstract}
ABSTRAK
Penelitian ini bertujuan untuk meningkatkan aktivitas dan hasil belajar siswa melalui model pembelajaran Jigsaw. Jenis penelitian ini adalah penelitian tindakan kelas (PTK). Penelitian ini dilakukan pada guru dan siswa SMK NW Tembeng Putik jurusan Teknik komputer dan jaringan (TKJ) yang berjumlah 12 orang siswa, tepatnya mata pelajaran yang digunakan adalah pendidikan pancasila dan kewarganegaraan (PKWn). Metode pengumpulan data dilakukan melalui metode wawancara, observasi, tes dan dokumentasi. Teknik analisis data menggunakan metode yang meliputi pengumpulan data, reduksi data, penyajian data, dan penarikan kesimpulan. Hasil penelitian ini menunjukkan adanya peningkatan aktivitas dan Prestasi belajar Pendidikan Pancasila dan kewarganegaraan. hal ini dapat dilihat melalui indikator sebagai berikut: kemampuan dalam mengemukakan gagasan berpikir saat kegiatan belajar mengajar ada 4 siswa setelah tindakan menjadi 8 siswa. keaktifan bertanya kepada guru dalam kegiatan belajar mengajar ada 3 siswa setelah tindakan menjadi 9 siswa. kemampuan berdiskusi dengan kelompok belajar ada 5 siswa setelah tindakan menjadi 11 siswa. siswa yang memiliki nilai memenuhi KKM ( $\geq 75)$ ada 5 siswa setelah tindakan menjadi 10 siswa. Kesimpulan penelitian ini adalah model pembelajaran jigsaw dapat meningkatkan aktivitas dan prestasi belajar Pendidikan Pancasila dan kewarganegaraan (Pkwn) siswa kelas XI SMK NW Tembeng Putik.
\end{abstract}

Kata kunci: Aktivitas belajar, Prestasi belajar, Model pembelajaran jigsaw. 


\section{PENDAHULUAN}

Perkembangan suatu bangsa erat sekali hubungannya dengan masalah-masalah pendidikan. Pendidikan merupakan suatu wadah sebagai pencetak sumber daya manusia (SDM) yang baik. Peningkatan kualitas pembelajaran merupakan salah satu dasar peningkatan pendidikan secara keseluruhan. Upaya peningkatan mutu pendidikan menjadi bagian terpadu dari upaya peningkatan kualitas manusia, baik aspek kemampuan, kepribadian, maupun tanggung jawab sebagai anggota dari masyarakat, sebab Pendidikan merupakan suatu upaya untuk mengembangkan segenap potensi yang ada pada diri siswa dengan tujuan memiliki kekuatan spiritual keagamaan, pengendalian diri, kepribadian, kecerdasan, akhlak mulia, serta keterampilan yang diperlukan bagi dirinya, masyarakat, bangsa, dan Negara. Dalam proses pendidikan, siswa diberikan bimbingan, arahan, dan latihan untuk dapat meningkatkan kecerdasan, keterampilan, dan sarana pembentukan sikap ${ }^{1}$.

Pendidikan pancasila dan Kewarganegaraan (PKWn) merupakan mata pelajaran yang bertugas membentuk warga negara yang baik, warga negara yang sadar akan hak dan kewajibannya. Dengan sadar akan hak dan kewajibannya maka seseorang warga negara diharapkan menjadi kritis, partisipasif dan bertanggungjawab. Namun dalam kenyataannya, tingkat keberhasilan Pendidikan pancasila dan Kewarganegaraan dalam membentuk manusia yang berkualitas sangatlah rendah. Hal ini disebabkan oleh rendahnya aktivitas peserta didik dalam mempelajari Pendidikan pancasila dan Kewarganegaraan, ini dapat dilihat dari prestasi peserta didik yang cenderung biasa-biasa saja. Sebagian peserta didik menganggap bahwa mata pelajaran PKWn termasuk mata pelajaran yang membosankan. Hal ini dapat dilihat ketika proses pembelajaran berlangsung, peserta didik kurang perhatian, kurang antusias, kurang respon terhadap pertanyaan, tidak pernah mengajukan pertanyaan, banyak yang belajar hanya ketika ada ulangan, mengerjakan pekerjaan rumah di sekolah serta tidak memiliki motivasi untuk mempelajari dan mencapai prestasi yang tinggi, sehingga nilai rata-rata kelas masih di bawah Kriteria Ketuntasan Minimal (KKM). Peserta didik menganggap bahwa pelajaran Pendidikan pancasila dan Kewarganegaraan adalah pelajaran yang mudah dan tidak terlalu penting. Hal ini dapat menimbulkan rendahnya minat, motivasi dan keaktifan serta prestasi peserta didik terhadap pelajaran Pendidikan pancasila dan Kewarganegaraan.

Guru merupakan komponen penting dalam belajar mengajar yang berinteraksi langsung dengan peserta didik. Guru mempunyai peranan yang sangat penting terhadap terciptanya proses pembelajaran yang ditetapkan. Masalah yang dirasakan adalah masih banyaknya guru yang mengalami kesulitan dalam menciptakan pembelajaran yang kondusif bagi peserta didik. Untuk menciptakan suasana belajar yang kondusif, peseta didik sangat dituntut untuk aktif dalam pelaksanaan pembelajaran demi tercapainya tujuan. Aktivitas yang harus dimiliki peserta didik perlu didukung oleh penentuan strategi pembelajaran yang sesuai dengan keadaan peserta didik dan lingkungan sekolah agar bisa diterapkan strategi pembelajaran yang efektif. Keterlibatan peserta didik secara aktif dalam proses belajar yang diharapkan adalah keterlibatan secara mental (intelektual dan emosional) yang dalam berbagai hal disertai aktivitas belajar peserta didik secara fisik sehingga peserta didik betul-betul aktif dalam proses pembelajaran.

\footnotetext{
${ }^{1}$ Abdurrahman. 2003. Pendidikan Bagi Anak Berkesulitan Belajar. Jakarta: PT. Rineka Cipta.
} 
Keterlibatan secara mental dalam hal ini adalah ketika proses pembelajaran, pikiran, perasaan dan perhatian peserta didik terfokus pada materi yang sedang dipelajari ${ }^{2}$.

Aktivitas dan prestasi belajar merupakan peranan vital dan saling berhubungan satu sama lain dalam kegiatan belajar mengajar di kelas. "mengajar adalah membimbing kegiatan belajar siswa sehingga ia mau belajar. Dengan demikian, aktivitas murid sangat diperlukan dalam kegiatan, belajar mengajar sehingga muridlah yang seharusnya banyak aktif, sebab murid sebagai subjek didik adalah yang merencanakan dan ia sendiri yang melaksanakan belajar"3.

Hasil observasi pendahuluan di kelas XI SMK NW Tembeng Putik tahun 2021/2022 diperoleh tingkat aktivitas dan prestasi belajar yang bervariasi. Diperoleh data bahwa tingkat aktivitas dan hasil belajar siswa ditinjau dari: 1) kemampuan dalam mengemukakan gagasan berpikir $(29,40 \%)$, 2) keaktifan bertanya kepada guru dalam kegiatan belajar mengajar (26,40\%), 3) kemampuan berdiskusi dengan kelompok belajar (38,20\%). Dari data tersebut menunjukkan bahwa tingkat aktivitas belajar siswa dalam belajar Pendidikan Pancasila dan kewarganegaraan (PKWn) sangatlah rendah. Selanjutnya diperoleh data siswa yang memiliki nilai memenuhi Kriteria Ketuntasan Minimal (KKM) ( $\geq 75)$ sebanyak 5 siswa (35,20\%). Dari data tersebut menunjukkan bahwa prestasi belajar siswa masih rendah.

Ketidakmampuan siswa disebabkan karena kurangnya guru untuk memahami dan membuat suasana pembelajaran yang menarik, guru masih menggunakan metode konvensional dalam pembelajaran. "keterlibatan siswa dalam belajar erat kaitannya dengan sifat-sifat murid, baik yang bersifat kognitif seperti kecerdasan dan bakat maupun yang bersifat afektif seperti motivasi, rasa percara". Proses belajar PKWn yang baik adalah guru harus mampu membuat suasana belajar yang menyenangkan dan mudah diterima oleh siswa, sehingga siswa tergerak untuk melakukan aktifitas dalam pembelajaran karena Pendidikan Pancasila dan Kewarganegaraan (PKWn) merupakan salah satu mata pelajaran yang mempersiapkan anak didik menjadi warga negara yang cerdas, bertanggung jawab, dan berkeadaban ${ }^{4}$.

Berdasarkan penyebab masalah-masalah tersebut sangat perlu melakukan penelitian berupa penelitian tindakan kelas (PTK) dengan mencoba menggunakan model pembelajaran kooperatif atau cooperative learning yang sedang gencar disosialisasikan sebagai alternatif dan berharap dengan metode ini bisa meningkatkan aktifitas dan prestasi belajar siswa. pembelajaran kooperative merujuk pada berbagai macam metode pengajaran dimana para siswa bekerja dalam kelompok-kelompok kecil untuk saling membantu satu sama lainnya dalam mempelajari materi pelajaran ${ }^{5}$.

Salah satu metode yang akan digunakan adalah model kooperatif tipe Jigsaw. Dengan mengambil atau meneliti aktivitas dan prestasi belajar siswa maka akan dapat mengetahui keberhasilan model kooperatif tipe Jigsaw ini dapat berkontribusi baik di dalam proser belajar mengajar ${ }^{6}$.

${ }^{2}$ Baharuddin, H., \& Wahyuni, E. N. (2010). Teori belajar dan pembelajaran. Yogyakarta: Arruz Media.

${ }^{3}$ Isjoni. 2013. Cooperative Learning Mengembangkan Kemampuan Belajar Berkelompok. Bandung: Alfabeta.

${ }^{4}$ Baharuddin, H., \& Wahyuni, E. N. (2010). Teori belajar dan pembelajaran. Yogyakarta: Arruz Media.

${ }^{5}$ Arikunto, Suharsimi. dkk. 2008. Penelitian Tindakan Kelas. Jakarta: Bumi Aksara.

${ }^{6}$ Mangduo, Qiao \& Jin Xiaoling. 2010. Jigsaw Strategi as a Cooperative Learning Technique: Focus on the Language Learners. Chinese Journal of Aplied Linguistics (Bimonthly), 33(4): 113-125. Harbin Institute of 


\section{METODE}

Penelitian ini merupakan penelitian tindakan kelas (PTK), atau Classroom Action Research. penelitian tindakan kelas merupakan suatu pencermatan terhadap kegiatan belajar berupa sebuah tindakan, yang sengaja di lakukan di kelas dengan tujuan untuk memperbaiki atau meningkatkan mutu praktik pembelajaran ${ }^{7}$. Penelitian ini dilaksanakan di SMK NW Tembeng Putik. Peneliti mengadakan penelitian di SMK NW Tembeng Putik dengan pertimbangan bahwa: (1) sekolah tersebut mengalami permasalahan aktivitas belajar, salah satunya pada mata pelajaran Pendidikan pancasila dan kewarganegaraan (PKWn), (2) sekolah tersebut mengalami permasalahan prestasi belajar, (3) sekolah tersebut dipilih peneliti karena lokasinya lumayan dekat dengan tempat tinggal peneliti.

Dalam penelitian ini, subjek pemberian tindakan adalah guru mata pelajaran pendidikan pancasila dan kewarganegaraan (PKWn) SMK NW Tembeng Putik, siswa kelas XI jurusan Teknik komputer dan jaringan (TKJ) SMK NW Tembeng Putik yang berjumlah 12 siswa terdiri dari 8 siswa laki-laki dan 4 siswa perempuan sebagai subjek penerima tindakan, sedangkan peneliti berperan sebagai observer atau pengamat. Peneliti juga bertugas dalam merencanakan, mengumpulkan data, menganalisis data, dan menarik kesimpulan saat penelitian dilaksanakan. Penelitian yang dilakukan merupakan penelitian tindakan kelas, yang dilakukan oleh guru, siswa, dan peneliti secara kolaboraif. Langkah-langkah penelitian tindakan kelas dibuat lebih efektif dan efisien guna meningkatkan kemampuan aktivitas dan prestasi belajar siswa dalam proses pembelajaran.

Data ini diperoleh dari kegiatan guru dalam proses pembelajaran Pendidikan Pancasila dan kewarganegaraan (PKWn). Pengumpulan data dalam penelitian ini, meliputi wawancara, observasi, catatan lapangan, metode tes dan dokumentasi.

Validitas data bertujuan menjamin kemantapan dan keabsahan data yang telah digali, dikumpulkan, dan dicatat dalam kegiatan penelitian untuk memilih dan menentukan cara-cara yang tepat untuk mengembangkan validitas data yang diperolehnya. Dalam penelitian ini akan digunakan triangulasi sumber dan teknik. Triangulasi adalah teknik pemeriksaan keabsahan data yang memanfaatkan suatu aspek yang lain dari luar data yang diteliti, untuk keperluan pengecekan atau sebagai pembanding terhadap data tersebut.

\section{HASIL}

Sebelum melakukan penelitian, peneliti memberi penjelasan bahwa pembelajaran yang akan dilakukan adalah pembelajaran kooperatif, yaitu dengan menggunakan model Jigsaw. Dengan tahapan; pembagian kelompok, pemberian materi dan kartu ahli, belajar secara individual, pembentukan kelompok ahli, diskusi dalam kelompok ahli, kembali kedalam kelompok asal, melalukan presentasi di kelompok, tes, penghitungan nilai kelompok, dan pemberian penghargaan bagi kelompok terbaik. Pembagian kelompok dibentuk oleh peneliti dengan mempertimbangkan ranking prestasi semester satu dan jenis kelamin. Setiap kelompok

\footnotetext{
${ }^{7}$ Sutama. 2011. Penelitian Tindakan Teori dan Praktek dalam PTK, PTS, danPTBK. Semarang: CV. Citra Mandiri Utama.
} 
terdiri dari peserta didik yang memiliki ranking tinggi, sedang dan rendah, serta lakilaki dan perempuan.

Peneliti juga menjelaskan dalam kegiatan pembelajaran setiap kelompok memberi penomoran sendiri sesuai jumlah kelompok, setelah itu diberikan materi yang berbeda untuk dibaca. Kartu ahli yang berisi pertanyaan yang harus dijawab oleh masing-masing anggota kelompok sesuai materi yang telah dibaca. Selanjutnya anggota yang bernomor 1, berkumpul dan berkelompok dengan anggota yang bernomor 1 dari kelompok lain dan membentuk kelompok ahli untuk soal nomor 1, yang kemudian disebut tim ahli 1. Anggota bernomor 2 berkumpul dengan anggota bernomor 2 dari kelompok lain dan membentuk kelompok ahli 2, dan seterusnya. Masing-masing kelompok ahli berdiskusi dan mencari jawaban atas permasalahan yang mereka terima. Setelah itu anggota tim ahli kembali ke dalam kelompok semula, kemudian melakukan presentasi secara bergilir di kelompoknya mulai dari anggota tim ahli 1 sampai 4. Setelah Presentasi, bersama guru menyimpulkan pembelajaran, dilanjutkan tes individual. Nilai tes individu dijumlahkan dengan teman dalam kelompok sehingga menjadi nilai kelompok.

Dalam belajar kelompok setiap peserta didik harus berperan aktif mulai dari mendengarkan perintah guru, membaca materi, berdiskusi, presentasi, mendengarkan presentasi teman satu kelompok, dan mengerjakan tes. Peneliti menjelaskan bahwa dengan model Jigsaw ini melatih kemampuan peserta didik untuk sangat aktif dan saling membantu untuk memecahkan masalah bersama, sehingga nantinya akan sangat bermanfaat dalam kehidupan.

Sebelum penelitian tindakan kelas dilakukan, peneliti melakukan pengamatan terhadap aktivitas belajar peserta didik. Hasilnya kemampuan dalam mengemukakan gagasan berpikir saat kegiatan belajar mengajar hanya ada 4 siswa, keaktifan bertanya kepada guru dalam kegiatan belajar mengajar ada 3 siswa, kemampuan berdiskusi dengan kelompok belajar ada 5 siswa dan siswa yang memiliki nilai memenuhi $\operatorname{KKM}(\geq 75)$ hanya 5 siswa.

Berdasarkan pembelajaran yang dilakukan secara menyeluruh pada tindakan siklus I dan siklus II pada siswa kelas XI jurusan Teknik komputer dan jaringan (TKJ) SMK NW Tembeng Putik dengan penerapan metode jigsaw, bahwa terjadi peningkatan aktivitas belajar siswa dalam pembelajaran Pendidikan Pancasila dan kewarganegaraan (PKWn). Peningkatan yang terjadi sesuai dengan indikator yang telah digunakan oleh peneliti yang meliputi: Siswa yang berani mengemukakan gagasan saat kegiatan belajar mengajar, Siswa yang berani bertanya tentang materi yang belum dipahami, Siswa yang berdiskusi dengan siswa lain. Data yang diperoleh peneliti tentang aktivitas belajar Pendidikan Pancasila dan kewarganegaraan (PKWn) pada siswa kelas XI jurusan Teknik komputer dan jaringan (TKJ) SMK NW Tembeng Putik, mulai dari sebelum tindakan sampai dengan tindakan siklus II disajikan dalam tabel berikut:

Tabel 4. 1

Data Peningkatan Aktivitas Siswa

\begin{tabular}{|l|c|c|c|}
\hline Aktivitas Siswa & Sebelum Tindakan & Siklus I & Siklus II \\
\hline
\end{tabular}




\begin{tabular}{|c|c|c|c|}
\hline $\begin{array}{c}\text { Mengemukakan } \\
\text { gagasan/pendapat }\end{array}$ & $\begin{array}{c}4 \text { siswa } \\
(29,40 \%)\end{array}$ & $\begin{array}{c}6 \text { siswa } \\
(55,80 \%)\end{array}$ & $\begin{array}{c}8 \text { siswa } \\
(76,40 \%)\end{array}$ \\
\hline $\begin{array}{c}\text { Keberanian } \\
\text { bertanya tentang } \\
\text { materi yang belum } \\
\text { dipahami }\end{array}$ & $\begin{array}{c}3 \text { siswa } \\
(26,40 \%)\end{array}$ & $\begin{array}{r}5 \text { siswa } \\
(50 \%)\end{array}$ & $\begin{array}{c}9 \text { siswa } \\
(82 \%)\end{array}$ \\
\hline $\begin{array}{c}\text { Berdiskusi dengan } \\
\text { siswa lain }\end{array}$ & $\begin{array}{c}5 \text { siswa } \\
(38,20 \%)\end{array}$ & $\begin{array}{c}8 \text { siswa } \\
(58,82 \%)\end{array}$ & $\begin{array}{c}11 \text { siswa } \\
(88,20 \%)\end{array}$ \\
\hline
\end{tabular}

Adapun grafik peningkatan aktivitas belajar Pendidikan Pancasila dan kewarganegaraan (PKWn) pada siswa kelas XI jurusan Teknik komputer dan jaringan (TKJ) SMK NW Tembeng Putik dengan penerapan metode jigsaw dari sebelum tindakan sampai sesudah tindakan siklus II dapat digambarkan sebagai berikut: 
Jurnal At Tadbir STAI Darul Kamal NW Kembang kerang NTB

Volume 2 No 1 Tahun 2022

P-ISSN : 2580-3433

E-ISSN : 2715-7210

https://journal.staidk.ac.id/index.php/tadbir

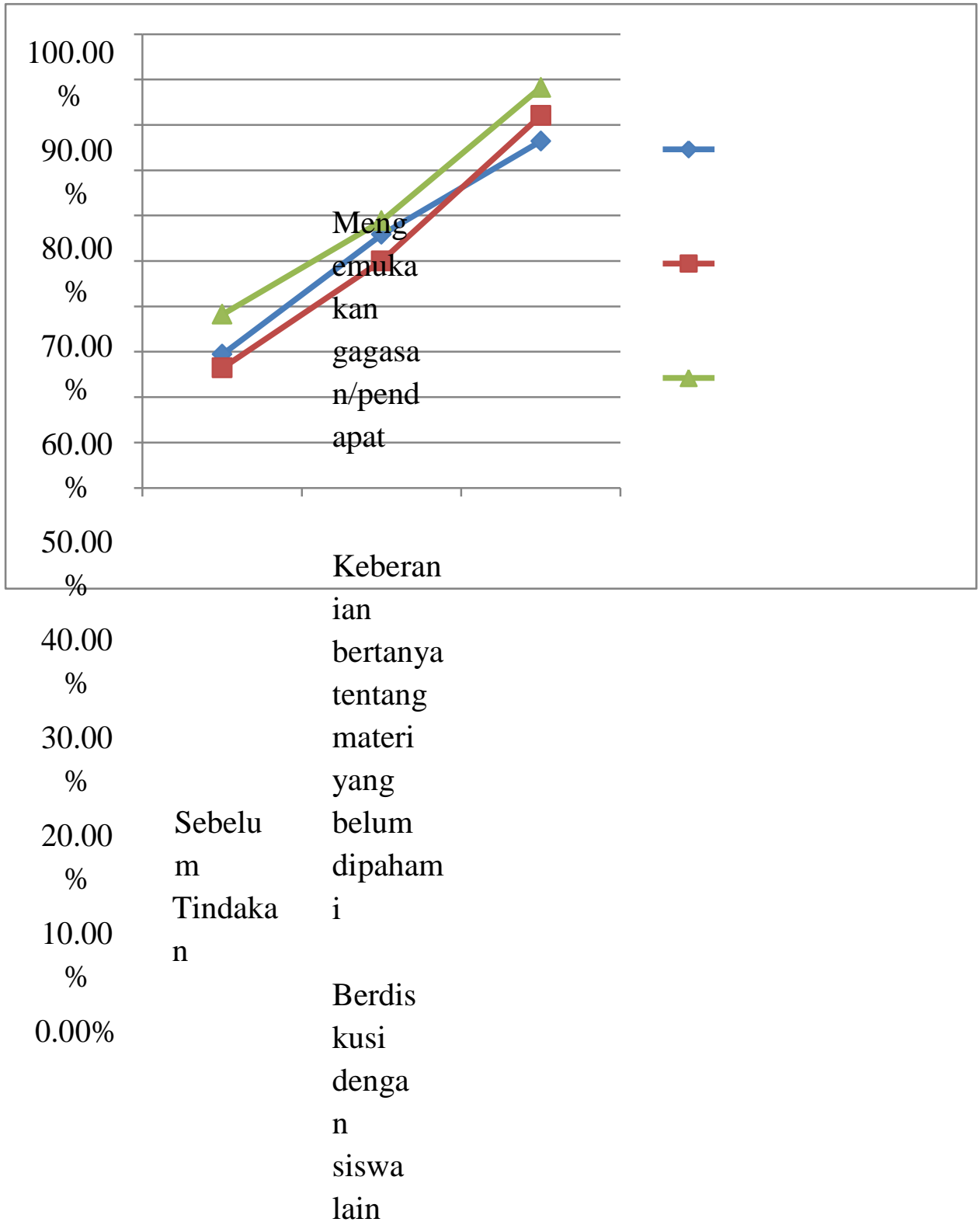


Berdasarkan pembelajaran yang dilakukan secara menyeluruh pada tindakan siklus I dan siklus II pada siswa kelas kelas XI jurusan Teknik komputer dan jaringan (TKJ) SMK NW Tembeng Putik dengan penerapan metode jigsaw, bahwa terjadi peningkatan prestasi belajar siswa dalam pembelajaran PKWn. Peningkatan yang terjadi sesuai dengan indikator yang telah digunakan oleh peneliti yaitu siswa yang lulus nilai KKM. Data yang diperoleh peneliti tentang prestasi belajar Pendidikan Pancasila dan kewarganegaraan pada siswa kelas XI jurusan Teknik komputer dan jaringan (TKJ) SMK NW Tembeng Putik, mulai dari sebelum tindakan sampai dengan tindakan siklus II disajikan dalam tabel berikut:

Tabel 4. 2

Data Peningkatan Prestasi Siswa

\begin{tabular}{|l|l|l|l|}
\hline \multicolumn{1}{|c|}{ Prestasi Siswa } & $\begin{array}{c}\text { Sebelum } \\
\text { Tindakan }\end{array}$ & Siklus I & Siklus II \\
\hline Lulus nilai Kriteria Ketuntasan & 5 siswa & 8 siswa & 10 siswa \\
Minimal (KKM) & $(35,20 \%)$ & $(67,64 \%)$ & $(85,20 \%)$ \\
\hline
\end{tabular}

Adapun grafik peningkatan prestasi belajar Pendidikan Pancasila dan kewarganegaraan (PKWn) pada siswa kelas XI SMK NW Tembeng Putik dengan penerapan metode jigsaw dari sebelum tindakan sampai sesudah tindakan siklus II dapat digambarkan sebagai berikut:

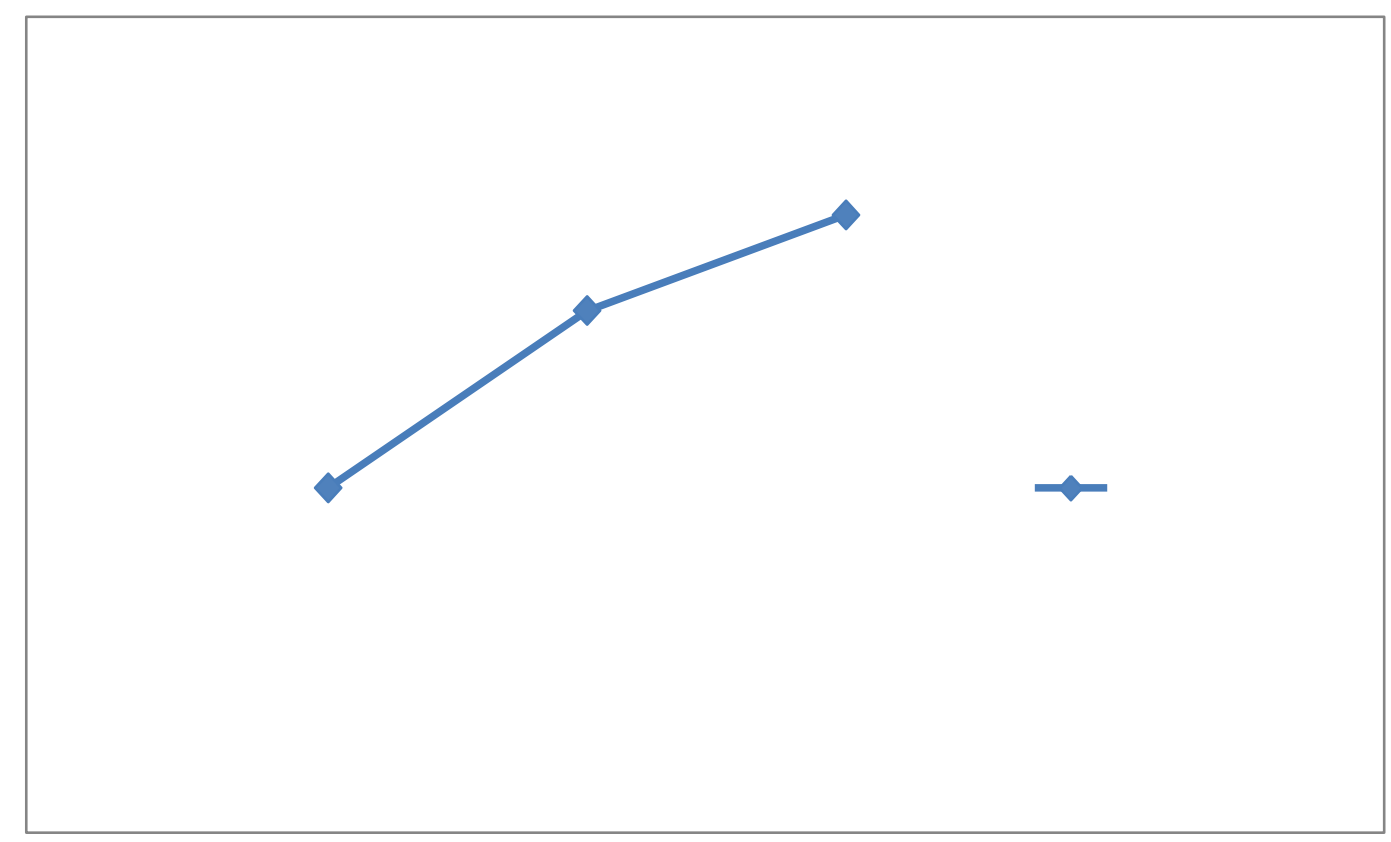




\begin{tabular}{|l|}
\hline $90.00 \%$ \\
\hline $80.00 \%$ \\
\hline $70.00 \%$ \\
\hline $60.00 \%$ \\
\hline $50.00 \%$ \\
\hline $40.00 \%$ \\
\hline $30.00 \%$ \\
\hline $20.00 \%$ \\
\hline $10.00 \%$ \\
\hline
\end{tabular}

\section{PEMBAHASAN}

Penelitian Tindakan Kelas ini dilaksanakan melalui dua siklus yang telah di rencanakan. Data mengenai peningkatan hasil belajar diambil dengan memberikan tes pilihan ganda yang diberikan pada akhir siklus. Subyek penelitian ini adalah guru dan siswa SMK NW Tembeng Putik jurusan Teknik komputer dan jaringan (TKJ) tahun pelajaran 2021/2022 yang berjumlah 12 orang siswa, dan dalam pelaksanaannya mulai dari siklus I sampai siklus II di ikuti oleh semua siswa. Pelaksanaan penelitian menerapkan model kooperatif tipe Jigsaw, yaitu dengan cara para siswa bekerja sama dalam kelompokkelompok kecil untuk saling membantu satu sama lainnya dalam mempelajari materi pelajaran.

Berdasarkan hasil refleksi pada siklus I dapat desampaikan bahwa rata-rata hasil belajar peserta didik adalah 67,64 Berdasarkan hal tersebut dapat dikatakan bahwa kriteria keberhasilan jika dilihat dari rata-rata hasil belajar peserta didik masih kurang terpenuhi. Daya serap peserta didik secara klasikal pada tahap refleksi awal adalah 67,64\%. Sedangkan Ketentun nilai KKM adalah 75. Jika dilihat dari kriteria keberhasilan bahwa pelaksanaan siklus I masih belum dapat dikatakan berhasil karena masih belum mencapai kriteria keberhasilan yang sudah ditetapkan.

Dengan adanya beberapa kendala yang di alami peserta didik, pelaksanaan penelitian dilanjutkan pada siklus II dengan melakukan penyesuaian jumlah peserta didik dalam satu kelompok diskusinya menjadi maksimal 4 orang. Hasil dari Penelitian tindakan kelas pada siklus II diperoleh rata-rata hasil belajar peserta didik adalah 85.20 dengan kualifikasi baik. Ketuntasan belajar peserta didik secara klasikal atau standar KKM adalah ( $\geq 75$ ). Berdasarkan analisis data terdapat peningkatan yang dialami selama penelitian pada tabel 2 tentang ringkasan analisis data hasil belajar PKWn peserta didik.

Berdasarkan hasil yang diperoleh, penelitian ini secara umum telah mampu memecahkan permasalahan yaitu dengan melaksanakan model pembelajaran kooperatif tipe Jigsaw dapat meningkatkan hasil belajar PKWn peserta didik di kelas XI TKJ SMK 
NW Tembeng Putik tahun pelajaran 2021/2022. Dengan kata lain penelitian tindakan kelas (PTK) yang dilakukan sudah berhasil.

\section{SIMPULAN DAN SARAN}

Berdasarkan hasil pembahasan di atas dapat disimpulkan pelaksanaan Penelitian tindakan kelas yang dilakukan di kelas XI SMK NW Tembeng Putik jurusan Teknik komputer dan jaringan (TKJ) tahun pelajaran 2021/2022 telah mengalami peningkatan aktivitas dan prestasi belajar siswa, dengan diterapkannya metode jigsaw dalam pembelajaran pendidikan pancasila dan kewarganegaraan (PKWn). Berdasarkan penelitian yang dilakukan secara kolaborasi antara guru PKWn dan peneliti, dapat diambil kesimpulan bahwa setelah dilakukan tindakan dari siklus I sampai siklus II dengan penerapan metode jigsaw dapat meningkatkan aktivitas belajar PKWn siswa yang dapat dilihat melalui indikator-indikatornya, yaitu: Siswa yang berani mengemukakan gagasan saat kegiatan belajar mengajar ada 4 siswa $(29,40 \%)$ menjadi 8 siswa $(76,40 \%)$. Siswa yang berani bertanya tentang materi yang belum dipahami ada 3 siswa $(26,40 \%)$ menjadi 9 siswa (82\%). Siswa yang berdiskusi dengan siswa lain ada 5 siswa $(38,20 \%)$ menjadi 11 siswa $(88,20 \%)$. Siswa yang lulus nilai KKM ada 5 siswa $(35,20 \%)$ menjadi 10 siswa $(85,20 \%)$. Hal ini menunjukkan bahwa pembelajaran pendidikan pancasila dan kewarganegaraan (PKWn) melalui penerapan metode jigsaw dapat meningkatkan aktivitas dan prestasi belajar PKWn siswa.

Adapun saran yang dapat disampaikan sehubungan dengan hasil penelitian ini antara lain: 1) Kepada rekan-rekan guru yang lain agar mengadakan penelitian guna mengembangkan pembelajaran yang dapat membantu peningkatan hasil belajar peserta didik; 2) Setiap guru hendaknya mampu memilih dan menyesuaikan model dan media pembelajaran sehingga pembelajaran dapat diikuti peserta didik dengan baik yang dapat berdampak pada hasil belajarnya. 


\section{Daftar Refrensi}

Abdurrahman. 2003. Pendidikan Bagi Anak Berkesulitan Belajar. Jakarta: PT. Rineka Cipta.

Adam, Francis H. 2013. Using Jigsaw Technique as an Effective Way of Promoting Cooperative Learning Among Primary Six Pupils in Fijai. International Journal Of Education and Practice, 1(6): 64-74. Holy Child Chollege Of Education.

Arikunto, Suharsimi. dkk. 2008. Penelitian Tindakan Kelas. Jakarta: Bumi Aksara.

Trianto. 2009. Mendesain Model Pembelajaran Inovatif-Progresif. Jakarta: Kencana Prenada Media Group.

Mangduo, Qiao \& Jin Xiaoling. 2010. Jigsaw Strategi as a Cooperative Learning Technique: Focus on the Language Learners. Chinese Journal of Aplied Linguistics (Bimonthly), 33(4): 113-125. Harbin Institute of Technology.

Isjoni. 2013. Cooperative Learning Mengembangkan Kemampuan Belajar Berkelompok. Bandung: Alfabeta.

Slavin, Robert E. 2009. Cooperative Learning Teori, Riset dan Praktik. (Diterjemahkan oleh: Lita). Bandung: Nusa Media.

Suprijono, Agus. 2014. Cooperative Learning Teori dan Aplikasi PAIKEM. Yogyakarta: Pustaka Pelajar.

Ismajanti, Ismajanti. 2013. Penerapan Model Pembelajaran Kooperatif Tipe Jigsaw Untuk Meningkatkan Hasil Belajar Siswa Pada Mata Pelajaran Pkn Siswa Sekolah Dasar. Jurnal Penelitian Pendidikan Guru Sekolah Dasar, 1(2): 1-5. Universitas Negeri Surabaya

Baharuddin, H., \& Wahyuni, E. N. (2010). Teori belajar dan pembelajaran. Yogyakarta: Arruz Media.

Sunarta. 2016. Peningkatan Aktivitas Dan Hasil Belajar Pkn Dengan Pembelajaran Kooperatif Tipe Jigsaw Di Kelas 8c Smp Negeri 3 Berbah. Jurnal Civics, 13(2): 151-161.

Sutama. 2011. Penelitian Tindakan Teori dan Praktek dalam PTK, PTS, dan PTBK. Semarang: CV. Citra Mandiri Utama.

Raditya, Angga dkk. 2014. Upaya Meningkatkan Keaktifan dan Prestasi Belajar Matematika Melalui Model Pembelajaran Jigsaw Siswa Kelas X SMK N 1 Magelang. Jurnal Pendidikan Matematika Union, 1(2): 69-74. Universitas Sarjanawiyata Tamansiswa. 